\title{
Basic science: (December 2005)
}

1. Akekawatchai C, Holland JD, Kochetkova M, Wallace JC, McColl SR. Transactivation of CXCR4 by the insulin-like growth factor-1 receptor (IGF-1R) in human MDA-MB-231 breast cancer epithelial cells. J Biol Chem 2005; 280: 39701-39708.

2. Andarawewa KL, Motrescu ER, Chenard MP, Gansmuller A, Stoll I, Tomasetto C, Rio MC. Stromelysin-3 is a potent negative regulator of adipogenesis participating to cancer celladipocyte interaction/crosstalk at the tumor invasive front. Cancer Res 2005; 65: 10862-10871.

3. Annicotte JS, Chavey C, Servant N, Teyssier J, Bardin A, Licznar A, Badia E, Pujol P, Vignon F, Maudelonde T, Lazennec G, Cavailles V, Fajas L. The nuclear receptor liver receptor homolog- 1 is an estrogen receptor target gene. Oncogene 2005; 24: 8167-8175.

4. Asanuma $\mathrm{H}$, Torigoe $\mathrm{T}$, Kamiguchi $\mathrm{K}$, Hirohashi $\mathrm{Y}$, Ohmura T, Hirata K, Sato M, Sato N. Survivin expression is regulated by coexpression of human epidermal growth factor receptor 2 and epidermal growth factor receptor via phosphatidylinositol 3-kinase/AKT signaling pathway in breast cancer cells. Cancer Res 2005; 65: 11018-11025.

5. Azuma $H$, Ehata $S$, Miyazaki $H$, Watabe $T$, Maruyama O, Imamura T, Sakamoto T, Kiyama S, Kiyama Y, Ubai T, Inamoto T, Takahara S, Itoh Y, Otsuki Y, Katsuoka Y, Miyazono K, Horie S. Effect of Smad7 expression on metastasis of mouse mammary carcinoma JygMC(A) cells. J Natl Cancer Inst 2005; 97: 1734-1746.

6. Bharadwaj S, Thanawala R, Bon G, Falcioni R, Prasad GL. Resensitization of breast cancer cells to anoikis by Tropomyosin-1: role of Rho kinase-dependent cytoskeleton and adhesion. Oncogene 2005; 24: 8291-8303.

7. Blask DE, Brainard GC, Dauchy RT, Hanifin JP, Davidson LK, Krause JA, Sauer LA, RiveraBermudez MA, Dubocovich ML, Jasser SA,

First published online 27/04/06

BCO/558/2006/JW
Lynch DT, Rollag MD, Zalatan F. Melatonindepleted blood from premenopausal women exposed to light at night stimulates growth of human breast cancer xenografts in nude rats. Cancer Res 2005; 65: 11174-11184.

8. Buchholz TA, Garg AK, Chakravarti N, Aggarwal BB, Esteva FJ, Kuerer HM, Singletary SE, Hortobagyi GN, Pusztai L, Cristofanilli M, Sahin AA. The nuclear transcription factor kappa B/bcl-2 pathway correlates with pathologic complete response to doxorubicin-based neoadjuvant chemotherapy in human breast cancer. Clin Cancer Res 2005; 11: 8398-8402.

9. Cullinane CA, Lubinski J, Neuhausen SL, Ghadirian P, Lynch HT, Isaacs C, Weber B, Moller P, Offit K, Kim-Sing C, Friedman E, Randall S, Pasini B, Ainsworth P, GershoniBaruch R, Foulkes WD, Klijn J, Tung N, Rennert G, Olopade O, Couch F, Wagner T, Olsson H, Sun P, Weitzel JN, Narod SA. Effect of pregnancy as a risk factor for breast cancer in BRCA1/BRCA2 mutation carriers. Int $J$ Cancer 2005; 117: 988-991.

10. Eddy SF, Guo SQ, Demicco EG, RomieuMourez R, Landesman-Borag E, Seldin DC, Sonenshein GE. Inducible I kappa B kinase/l kappa B kinase epsilon expression is induced by CK2 and promotes aberrant nuclear factorkappa B activation in breast cancer cells. Cancer Res 2005; 65: 11375-11383.

11. Gago-Dominguez M, Castelao JE, Pike MC, Sevanian A, Haile RW. Role of lipid peroxidation in the epidemiology and prevention of breast cancer. Cancer Epidemiol Biomar Prevent 2005; 14: 2829-2839.

12. Glunde K, Raman V, Mori N, Bhujwalla ZM. RNA interference-mediated choline kinase suppression in breast cancer cells induces differentiation and reduces proliferation. Cancer Res 2005; 65: 11034-11043.

13. Goetz MP, Rae JM, Suman VJ, Safgren SL, Ames MM, Visscher DW, Reynolds C, Couch FJ, 
Lingle WL, Flockhart DA, Desta Z, Perez EA, Ingle JN. Pharmacogenetics of tamoxifen biotransformation is associated with clinical outcomes of efficacy and hot flashes. J Clin Oncol 2005; 23: 9312-9318.

14. Hu X, Washington S, Verderame MF, Manni A. Interaction between polyamines and the mitogenactivated protein kinase pathway in the regulation of cell cycle variables in breast cancer cells. Cancer Res 2005; 65: 11026-11033.

15. Hu YF, Ghosh S, Amleh A, Yue W, Lu YZ, Katz A, $\mathrm{Li}$ R. Modulation of aromatase expression by BRCA1: a possible link to tissue-specific tumor suppression. Oncogene 2005; 24: 8343-8348.

16. Hunter DJ, Riboli E, Haiman CA, Albanes D, Altshuler D, Chanock SJ, Hayes RB, Henderson BE, Kaaks R, Stram DO, Thomas G, Thun MJ and Group Authors. The National Cancer Institute Breast Prostate Cancer Cohort Consortium. A candidate gene approach to searching for low-penetrance breast and prostate cancer genes. Nat Rev Cancer 2005; 5: 977-985.

17. Isakoff SJ, Engelman JA, Irie HY, Luo J, Brachmann SM, Pearline RV, Cantley LC, Brugge JS. Breast cancer-associated PIK3CA mutations are oncogenic in mammary epithelial cells. Cancer Res 2005; 65: 10992-11000.

18. Isidoro A, Casado $E$, Redondo A, Acebo $P$, Espinosa E, Alonso AM, Cejas P, Hardisson D, Fresno Vara JA, Belda-Iniesta C, GonzalezBaron M, Cuezva JM. Breast carcinomas fulfill the Warburg hypothesis and provide metabolic markers of cancer prognosis. Carcinogenesis 2005; 26: 2095-2104.

19. Kaaks R, Rinaldi S, Key TJ, Berrino F, Peeters PHM, Biessy C, Dossus L, Lukanova A, Binghan S, Khaw KTG, Allen NE, BuenoDe-Mesquita HB, van Gils CH, Grobbee D, Boeing $\mathrm{H}$, Lahmann PH, Nagel $\mathrm{G}$, ChangClaude J, Clavel-Chapelon F, Fournier A, Thiebaut A, Gonzalez CA, Quiros JR, Tormo MJ, Ardanaz E, Amiano P, Krogh V, Palli D, Panico S, Tumino R, Vineis P, Trichopoulou A, Kalapothaki V, Trichopoulos D, Ferrari P, Norat T, Saracci R, Riboli E. Postmenopausal serum androgens, oestrogens and breast cancer risk: the European prospective investigation into cancer and nutrition. Endocr-Relat Cancer 2005; 12: 1071-1082.

20. Kasper G, Weiser AA, Rump A, Sparbier K, Dahl E, Hartmann A, Wild P, Schwidetzky U, CastanosVelez E, Lehmann K. Expression levels of the putative zinc transporter LIV-1 are associated with a better outcome of breast cancer patients. Int $\mathrm{J}$ Cancer 2005; 117: 961-973.
21. Kumar R, Neilsen PM, Crawford J, McKirdy R, Lee J, Powell JA, Saif Z, Martin JM, Lombaerts M, Cornelisse CJ, Cleton-Jansen AM, Callen DF. FBXO31 is the chromosome 16q24.3 senescence gene, a candidate breast tumor suppressor, and a component of an SCF complex. Cancer Res 2005; 65: 11304-11313.

22. Larson PS, Schlechter BL, de las Morenas A, Garber JE, Cupples LA, Rosenberg CL. Allele imbalance, or loss of heterozygosity, in normal breast epithelium of sporadic breast cancer cases and BRCA1 gene mutation carriers is increased compared with reduction mammoplasty tissues. J Clin Oncol 2005; 23: 8613-8619.

23. Leong HY, Sloan JR, Nash PD, Greene GL. Recruitment of histone deacetylase 4 to the $\mathrm{N}$-terminal region of estrogen receptor alpha. Mol Endocrinol 2005; 19: 2930-2942.

24. Levenson AS, Thurn KE, Simons LA, Veliceasa D, Jarrett J, Osipo C, Jordan VC, Volpert OV, Satcher RL, Gartenhaus RB. MCT-1 oncogene contributes to increased In vivo tumorigenicity of MCF7 cells by promotion of angiogenesis and inhibition of apoptosis. Cancer Res 2005; 65: 10651-10656.

25. Lewis JS, Meeke K, Osipo C, Ross EA, Kidawi N, Li TY, Bell E, Chandel NS, Jordan VC. Intrinsic mechanism of estradiol-induced apoptosis in breast cancer cells resistant to estrogen deprivation. J Natl Cancer Inst 2005; 97: 1746-1759.

26. Li JN, Zhao J, Yu XD, Lange J, Kuerer $H$, Krishnamurthy S, Schilling E, Khan SA, Sukumar S, Chan DW. Identification of biomarkers for breast cancer in nipple aspiration and ductal lavage fluid. Clin Cancer Res 2005; 11: 8312-8320.

27. Li X, Zhang J, Gao HL, Vieth E, Bae KH, Zhang YP, Lee SJ, Raikwar S, Gardner TA, Hutchins GD, VanderPutten D, Kao CH, Jeng $\mathrm{MH}$. Transcriptional targeting modalities in breast cancer gene therapy using adenovirus vectors controlled by alpha-lactalbumin promoter. Mol Cancer Ther 2005; 4: 1850-1859.

28. Libertini SJ, Robinson BS, Dhillon NK, Glick D, George M, Dandekar S, Gregg JP, Sawai E, Mudryj M. Cyclin E both regulates and is regulated by calpain 2, a protease associated with metastatic breast cancer phenotype. Cancer Res 2005; 65: 10700-10708.

29. Lin HJ, Hsieh FC, Song H, Lin J. Elevated phosphorylation and activation of PDK-I/AKT pathway in human breast cancer. Brit $J$ Cancer 2005; 93: 1372-1381.

30. Mallory JC, Crudden G, Oliva A, Saunders C, Stromberg A, Craven RJ. A novel group of 
genes regulates susceptibility to antineoplastic drugs in highly tumorigenic breast cancer cells. Mol Pharmacol 2005; 68: 1747-1756.

31. Manka D, Spicer Z, Millhorn DE. Bcl-2/adenovirus E1B $19 \mathrm{kDa}$ interacting protein-3 knockdown enables growth of breast cancer metastases in the lung, liver, and bone. Cancer Res 2005; 65: 11689-11693.

32. Martin LA, Pancholi S, Chan CMW, Farmer I, Kimberley C, Dowsett M, Johnston SRD. The anti-oestrogen ICI 182,780, but not tamoxifen, inhibits the growth of MCF-7 breast cancer cells refractory to long-term oestrogen deprivation through down-regulation of oestrogen receptor and IGF signalling. Endocr-Relat Cancer 2005; 12: 1017-1036.

33. Martin SA, Ouchi T. BRCA1 phosphorylation regulates caspase-3 activation in UVinduced apoptosis. Cancer Res 2005; 65: 10657-10662.

34. Mehra R, Varambally S, Ding L, Shen RL, Sabel MS, Ghosh D, Chinnaiyan AM, Kleer CG. Identification of GATA3 as a breast cancer prognostic marker by global gene expression metaanalysis. Cancer Res 2005; 65: 11259-11264.

35. Mironchik Y, Winnard PT, Vesuna F, Kato $Y$, Wildes F, Pathak AP, Kominsky S, Artemov D, Bhujwalla Z, Van Diest P, Burger H, Glackin C, Raman V. Twist overexpression induces in vivo angiogenesis and correlates with chromosomal instability in breast cancer. Cancer Res 2005; 65: 10801-10809.

36. Nahta R, Yuan LYH, Zhang B, Kobayashi R, Esteva FJ. Insulin-like growth factor-I receptor/ human epidermal growth factor receptor 2 heterodimerization contributes to trastuzumab resistance of breast cancer cells. Cancer Res 2005; 65: 11118-11128.

37. Paglin S, Lee NY, Nakar C, Fitzgerald M, Plotkin J, Deuel B, Hackett N, McMahill M, Sphicas E, Lampen N, Yahalom J. Rapamycin-sensitive pathway regulates mitochondrial membrane potential, autophagy, and survival in irradiated MCF-7 cells. Cancer Res 2005; 65: 11061-11070.

38. Rody A, Holtrich $U$, Solbach $C$, Kourtis K, von Minckwitz G, Engels K, Kissler S, Gatje R, Karn T, Kaufmann M. Methylation of estrogen receptor beta promoter correlates with loss of ER-beta expression in mammary carcinoma and is an early indication marker for premalignant lesions. Endocr-Relat Cancer 2005; 12: 903-916.

39. Ruiz-Cortes ZT, Kimmins S, Monaco L, Burns KH, Sassone-Corsi P, Murphy BD. Estrogen mediates phosphorylation of histone H3 in ovarian follicle and mammary epithelial tumor cells via the mitotic kinase, aurora B. Mol Endocrinol 2005; 19: 2991-3000.

40. Santen RJ, Lobenhofer EK, Afshari CA, Bao Y, Song RX. Adaptation of estrogen-regulated genes in long-term estradiol deprived MCF-7 breast cancer cells. Breast Cancer Res Treat 2005; 94: 213-223.

41. Shaaban AM, Jarvis C, Moore F, West C, Dodson A, Foster CS. Prognostic significance of estrogen receptor beta in epithelial hyperplasia of usual type with known outcome. Am J Surg Pathol 2005; 29: 1593-1599.

42. So A, Sinnemann S, Huntsman D, Fazli L, Gleave M. Knockdown of the cytoprotective chaperone, clusterin, chemosensitizes human breast cancer cells both in vitro and in vivo. $\mathrm{Mol}$ Cancer Ther 2005; 4: 1837-1849.

43. Sotgia F, Williams TM, Cohen AW, Minetti C, Pestell RG, Lisanti MP. Caveolin-1-deficient mice have an increased mammary stem cell population with upregulation of $\mathrm{Wnt} / \mathrm{beta}$ catenin signaling. Cell Cycle 2005; 4: 18081816.

44. Suzuki T, Miki $Y$, Nakamura $Y$, Moriya $T$, Ito $K$, Ohuchi N, Sasano H. Sex steroid-producing enzymes in human breast cancer. Endocr-Relat Cancer 2005; 12: 701-720.

45. Symmans WF, Fiterman DJ, Anderson SK, Ayers M, Rouzier R, Dunmire V, Stec J, Valero V, Sneige N, Albarracin C, Wu Y, Ross JS, Wagner P, Theriault RL, Arun B, Kuerer H, Hess KR, Zhang W, Hortobagyi GN, Pusztai L. A single-gene biomarker identifies breast cancers associated with immature cell type and short duration of prior breastfeeding. Endocr-Relat Cancer 2005; 12: 1059-1069.

46. Vinatzer U, Dampier B, Streubel B, Pacher M, Seewald MJ, Stratowa C, Kaserer K, Schreiber M. Expression of HER2 and the coamplified genes GRB7 and MLN64 in human breast cancer: quantitative real-time reverse transcription-PCR as a diagnostic alternative to immunohistochemistry and fluorescence in situ hybridization. Clin Cancer Res 2005; 11: 8348-8357.

47. Wei MJ, Grushko TA, Dignam J, Hagos F, Nanda R, Sveen L, Xu JH, Fackenthal J, Tretiakova M, Das S, Olopade OI. BRCA1 promoter methylation in sporadic breast cancer is associated with reduced BRCA1 copy number and chromosome 17 aneusomy. Cancer Res 2005; 65: 10692-10699.

48. Zhang $\mathrm{H}$, Xie XY, Zhu XD, Zhu JH, Hao CF, Lu QJ, Ding LH, Liu YF, Zhou L, Liu YL, Huang CF, Wen CG, Ye QN. Stimulatory cross-talk between NFAT3 and estrogen receptor in breast cancer cells. J Biol Chem 2005; 280: 43188-43197. 
49. Zhao JJ, Liu ZN, Wang L, Shin E, Loda MF, Roberts TM. The oncogenic properties of mutant p110 alpha and p110 beta phosphatidylinositol 3-kinases in human mammary epithelial cells. Proc Natl Acad Sci USA 2005; 102: 18443-18448. 